\title{
MEDENÝ INGOT Z CHTELNICE
}

\author{
Z D E N ĚK F A R K A ̌̌
}

\begin{abstract}
Copper Ingot from Chtelnica. In the Lesser Carpathian mountain range, near the village of Chtelnica, Pieštany district, an unusual cylindrical copper ingot was discovered by accident, having a height of $11.9 \mathrm{~cm}$, probably melted down from chalcopyrite. The site of the find is located near several archaeological sites from the Eneolithic period, mainly from the period of the Ludanice group of the Lengyel culture and the Bajč-Retz group. The area of interest was repeatedly settled in the later to late Bronze Age. The unusual shape of the raw material and the presumed advanced technological processes of melting, however, do not enable us to define clearly the chronological classification of the ingot.
\end{abstract}

Keywords: Slovakia, Lesser Carpathians, Prehistory, copper ingot, ED-XRF analysis.

Okolo roku 2010 našli pracovníci Štátnych lesov pri lesnej účelovej kumunikácii vedúcej od vŕšku Bukovinky popod kopec Pálenice k bývalému polovníckemu zámočku Výtok, ktorý leží v Chtelnickej doline v katastri obce Chtelnica, okr. Pieštany, vel'ký medený ingot neúplného kuželovitého tvaru, údajne sprevádzaný iným, podstatne menším zlomkom medenej suroviny (obr. 1; 2). Od nich sa dostal prostredníctvom pracovníkov Štátneho podniku Lesy Slovenskej republiky, Lesného závodu Smolenice a CHKO Malé Karpaty v Modre do Slovenského národného múzea-Archeologického múzea v Bratislave (dalej SNM-AM). Menší kúsok vytavenej suroviny je dnes nezvestný a údajne bol poskytnutý na chemický rozbor do Trnavy.

Miesto nálezu leží vo vnútri Malých Karpát vo výrazne zvlnenom teréne v blízkosti kóty 316, približne $3,75 \mathrm{~km}$ severozápadne od vyústenia Chtelnickej doliny v obci a 1,3 km severne od ústia potoka Chtelničanka (Výtok) do Chtelnickej vodnej nádrže (JSTK Y 532741, X 1232866; obr. 1). Už lesní robotníci predpokladali, že predmet(y) niekto našiel detektorom kovov v širšom okolí a pri križovatke lesných ciest ho odložil bud' pre plánovaný transport pomocou motorového vozidla, alebo oň stratil záujem.

Kompaktná hruda výtavku s pórovitou štruktúrou a drobnými otvormi po úniku plynov si zachovala vnútorný tvar termického zariadenia s rovným dnom a kónicky dohora pod uhlom 107,6 $6^{\circ}$ sa rozširujúcimi stenami. Priemer spodnej časti ingotu sa pohyboval v rozmedzí 18 až $20 \mathrm{~cm}$. Gravitácia a rýchlejšie chladnutie masy pri dne a okrajoch sa prejavilo hutnejším a rovnejším povrchom týchto častí. Stred hrudy bol pórovitý, menej kompaktný. Obsahoval viac plynov, čo sa odzrkadlilo na rozpadnutí výtavku na niekol'ko samostatných častí. Podla jednoliatej patiny došlo $\mathrm{k}$ rozpadu dávno pred vyzdvihnutím ingotu zo zeme. Vrchná čast' hrudy je v strede mierne lavórovito prehnutá, s viacsmernými stopami po úprave pomerne úzkym pracovným nástrojom ešte $\mathrm{v}$ čiastočne plastickom stave, zrejme počas odstraňovania trosky a iných nečistôt $z$ jej povrchu. Nástroj zanechal po sebe plytké ryhy široké 0,35 až $0,5 \mathrm{~cm}$. Takmer kolmo na ne nadväzuje oškrabovaním zvlnený povrch aj s čiastočným vlnovitým sekundárnym preklopením podrezaného materiálu (obr. 2). $V$ predpokladanom pôvodnom strede spodnej časti ingotu je plytká prehĺbenina s priemerom $4,6 \mathrm{~cm}$, zasahujúca $0,7 \mathrm{~cm}$ pod pôvodnú úroveň hrudy. Vznikla opakovanými údermi „kladiva“ so štvorcovou hlavicou s rozmermi 2,5 x 2,6 cm. Tie spôsobili nevýrazné puklinky $\mathrm{v}$ materiáli a azda prispeli $\mathrm{k}$ rozpadu pôvodného ingotu na viac častí. Stopy úderov sú viditelné aj na viacerých miestach v okolí vrcholovej prehĺbeniny. Zahladený povrch dna, pôvodných bokov a niektorých výrazne vyčnievajúcich častí z tela azda možno spájat s čistením výtavku od zvyškov stien pece či kokily, trosky a iných prímesí, ktoré ostali na jej povrchu po ukončení metalurgického procesu.

Rozmery: nepravidelná spodná čast' $15 \times 11,9 \mathrm{~cm}$, stred $16,3 \times 14,7 \mathrm{~cm}$, vrch 9,3 x 8,6 cm, v. 11,9 cm. Dí. žliabkov po dlátovitom nástroji od 2,2 po $3 \mathrm{~cm}$. Váha: 4,654 g (obr. 2).

Tvar kovového ingotu pripomína výliatok spodnej časti jednoduchej šachtovej pece pôvodne aspoň čiastočne zapustenej do terénu. $V$ prípade tzv. nisteje sa však v jej spodnej časti zvyčajne usadzovali zvyšky paliva, hlušiny, trosky a pod., čo malo vplyv na nerovný spodný povrch ingotov, výrazne odlišný od nálezu z Chtelnice. Predmet sa predovšetkým výškou výtavku odlišuje od známych foriem suroviny od eneolitu až po včasný novovek (Sitár a i. 2012, 273, 274). Už od počiatku stredného eneolitu sa $\mathrm{v}$ stredoeurópskom priestore 


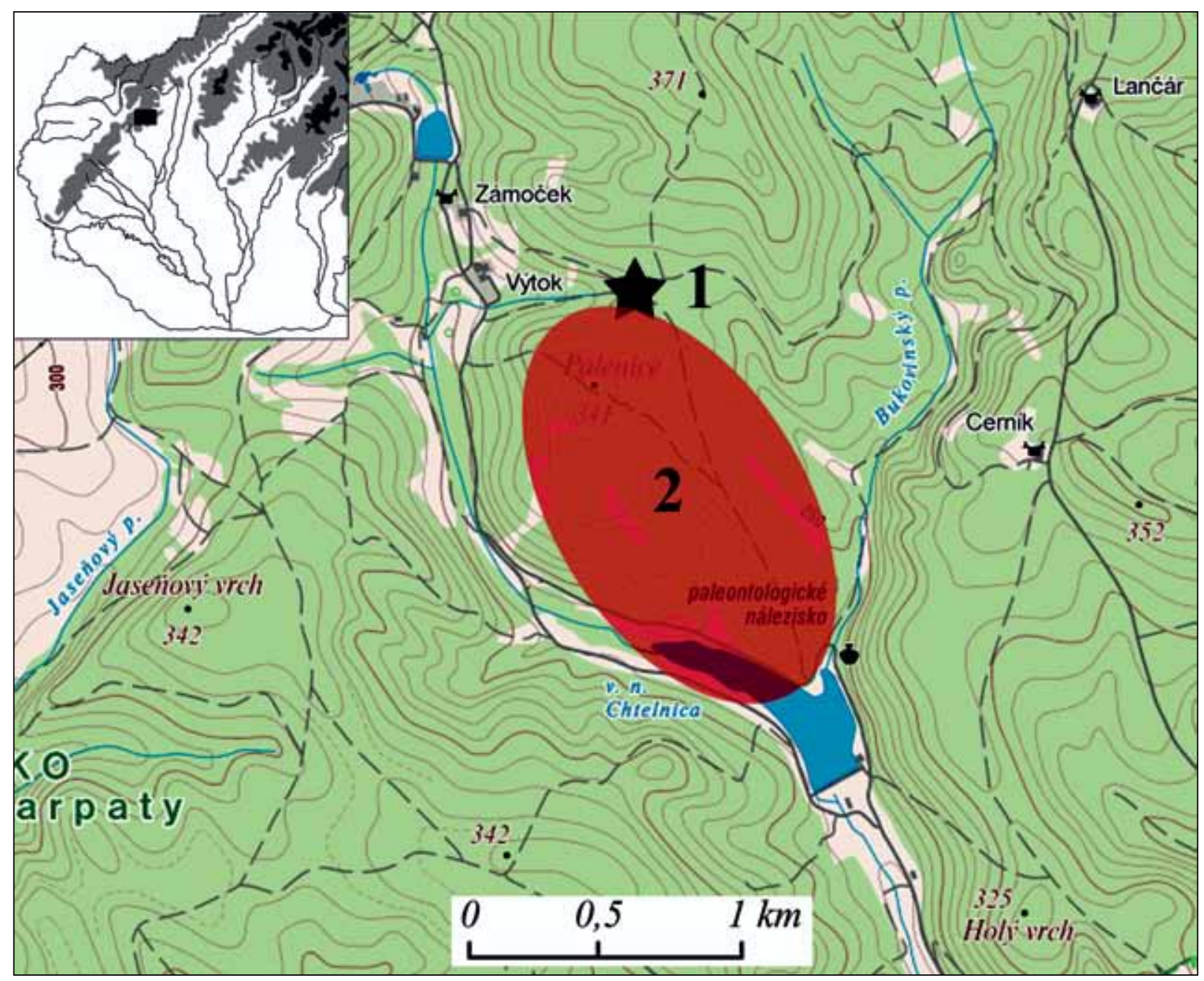

Obr. 1. Mapa Malých Karpát v okolí Chtelnice. 1 - poloha Pálenice, miesto nálezu medeného ingotu; 2 - Stará Chtelnica a Pálenice, predpokladaný rozsah eneolitického osídlenia (zdroj mapového podkladu: https://mapy.hiking.sk/).

objavujú okrem amorfných zliatkov ako forma suroviny aj plankonvexné kruhové koláče, známe napr. z hromadného nálezu v Handlovej (Budaváry 1930, 95, 96; Novotná 1955, 89). Tie ako produkty jednoduchších taviacich zariadení či už jamového, alebo šachtového typu (Jiráň a kol. 2008, 12) pretrvávajú pomerne dlhú dobu a v podobe zlomkov v prostredí kultúr popolnicových polí zo stupňov BD-HA2/ HB1 sa objavujú aj v zdokumentovaných hromadných nálezoch v malokarpatskej oblasti z Bukovej a zo Svätého Jura (Bartík/Farkaš/Jelínek 2019, 21-26, 39-43). Od staršej doby bronzovej, predovšetkým v prostredí únětickej kultúry, už medená surovina po vyčistení (rafinácii) dostávala aj ustálený tvar v podobe nákrčníkových hrivien, prípadne tzv. rebier, vhodných na transport z primárnych metalurgických centier a zodpovedajúcich požiadavkám s nimi spätej tovarovej výmeny. V stredoveku a na začiatku novoveku, počas rozkvetu slovenského medenorudného baníctva, mala obchodovaná suro- vina štandardizované tvary vhodné pre transport, niekedy so značkou „exportnej“ spoločnosti (Sitár a i. 2012, 273, 274). Formou suroviny boli aj kruhové koláče $\mathrm{s}$ vystupujúcimi okrajmi pripomínajúce pizzu, ktoré sa podarilo nájst' v koryte Váhu pri Kočovciach (Mádl 1936, 110, 111) a Hlohovci (Novosedlík2002, 143, 144). Podla všetkého vznikli naliatím tekutého kovu do plytkej kruhovej priehlbne (Mádl 1936, 111). Ani v tomto prípade nie je ich datovanie jednoznačné (Bátora/Furmánek 2015, 277) a pohybuje sa od mladšej, prípadne neskorej doby bronzovej až po stredovek. Ich vyzdvihnutie z toku Váhu naznačuje možný transport od primárnych zdrojov prostredníctvom vodných komunikácií.

Hrúbka ingotu z Chtelnice $(11,9 \mathrm{~cm})$, kompaktnost' hmoty a váha poukazujú na zvládnutý technologický postup za nevyhnutného striedania oxidačného a redukčného prostredia (Jiráň a kol. 2008, 12), pričom vytavený kov sa mohol z pece získavat pomocou "odpichu“ do pripravenej keramickej 


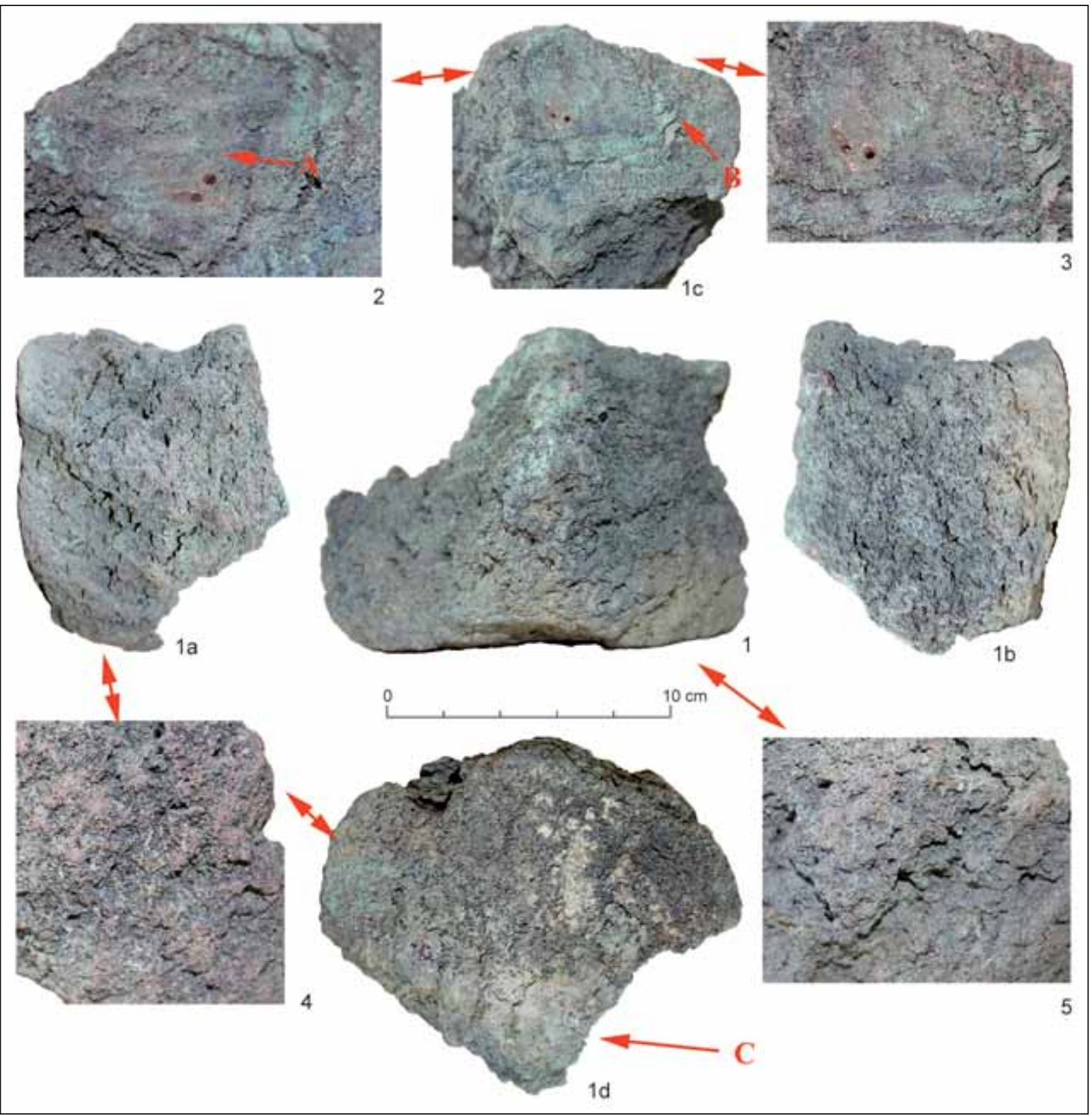

Obr. 2. Chtelnica, poloha Pálenice. Medený ingot. 1 - pohlady na výtavok z rôznych strán; 1c - vrchná čast’ so stopami úpravy povrchu ešte v plastickom stave; 2, 3 - detaily vrchnej časti: A - stopy po odstraňovaní „trosky“; B - sekundárne vlnovité preklopenie tenkej vrstvy kovu, 1d - spodok ingotu: C - stopy úderov nástroja s kvadratickou hlavicou; 4,5 - detaily povrchu (foto Z. Farkaš).

alebo do zeme vyhĺbenej formy. Nasledovné úpravy, predovšetkým stopy po odstraňovaní trosky z povrchu hrudy, sa uskutočnili krátko po tavbe, $\mathrm{v}$ dobe, ked' sa masa nachádzala ešte $\mathrm{v}$ čiastočne plazmatickom stave.

Nezvyklý tvar hrudy suroviny a neznáme okolnosti nálezu neumožňujú jednoznačné časové zaradenie predmetu, hoci väčšina indícií naznačuje jeho mladší, azda postpraveký pôvod. Chemické zloženie materiálu (tabela 1) ${ }^{1}$ bolo skúmané ED-XRF analýzou, ručným röntgen-fluorescenčným spektrometrom DELTA CLASSIC+ od firmy Olympus, USA (J. Tirpák) na Fakulte prírodných vied Univerzity Konštantína Filozofa v Nitre a metódou ED-XRF

1 Za zostavenie tabely a jej vyhodnotenie dakujem T. Zacharovi z Institut für Ur- und Frühgeschichte, Philosophische Fakultät Universität zu Köln. 
Tabela 1. Chtelnica. Medený ingot. Porovnávacia tabul'ka s chemickým zložením výtavku.

\begin{tabular}{|c|c|c|c|c|c|c|c|c|c|c|c|c|c|c|c|}
\hline Vzorka & Metóda & Inštitúcia & $\mathrm{Fe}$ & Co & $\mathrm{Ni}$ & $\mathrm{Cu}$ & $\mathrm{Zn}$ & As & $\mathbf{A g}$ & Sn & Sb & $\mathrm{Au}$ & $\mathrm{Pb}$ & $\mathbf{B i}$ & $\mathbf{S i}$ \\
\hline Chtelnica & ED-XRF & $\begin{array}{l}\text { Ústav geolo- } \\
\text { gických vied } \\
\text { PřF MU Brno }\end{array}$ & 0.1060 & $<$ LOD & 2.1400 & 92.4 & $<$ LOD & 1.0900 & 0.1300 & $<$ LOD & 1.6700 & $<$ LOD & 1.0200 & $<$ LOD & 1.4600 \\
\hline Chtelnica & ICP-OES & $\begin{array}{l}\text { Ústav chemie } \\
\text { PřF MU Brno }\end{array}$ & 0,032 & $\mathrm{n}$ & 2,209 & 93,54 & $\mathrm{n}$ & 1,159 & 0,1264 & $<$ LOD & 1,349 & $\mathrm{n}$ & 0,560 & $\mathrm{n}$ & $\mathrm{n}$ \\
\hline Chtelnica & XRF & $\begin{array}{c}\text { Gemologický } \\
\text { ústav FPV } \\
\text { UKF Nitra }\end{array}$ & $<$ LOD & $<$ LOD & 1,67 & 93,82 & 0,6 & 1,59 & $<$ LOD & $<$ LOD & 1 & $<$ LOD & 1,32 & $<$ LOD & $\mathrm{n}$ \\
\hline
\end{tabular}

$<\mathrm{LOD}=$ pod detekčným limitom

$\mathrm{n}=$ neanalyzované

a Inductively Couplet Plasma - Optical Emission na Ústave geologických věd Př́rodovědecké fakulty Masarykovy univerzity v Brne a poukazuje na primárnu surovinu pravdepodobne zodpovedajúcu chalkopyritu.

Súčasné poznatky zatial neumožňujú jednoznačné časové zaradenie neobvyklého medeného ingotu nájdeného $\mathrm{v}$ Malých Karpatoch v blízkosti obce Chtelnica, okr. Pieštany, a to napriek tomu, že pochádzajú z miesta s pomerne intenzívnym osídlením tunajšieho horského prostredia s doposial' dvomi doloženými maximami. Jedným z nich je obdobie od prelomu neolitu a eneolitu až po začiatok vývoja badenskej kultúry a druhým mladšia až neskorá doba bronzová. Obidva časové úseky sa vyznačujú rozvinutou metalurgiou kovov. Ingot však zrejme nemožno spájat ani s jedným z nich.

\section{LITERATÚRA}

Bartík/Farkaš/Jelínek 2019 - J. Bartík/Z. Farkaš/P. Jelínek: Bronzehortfunde aus den Kleinen Karpaten und ihren Vorgebirgsgebieten. In: I. Bazovský/G. Březinová (ed.): Ludia a hory-archeologická perspektíva. Interakcie l'udských spoločenstiev horských a podhorských oblastí západného Slovenska. Zborník SNM. Archeológia. Supplementum 12. Bratislava - Nitra 2019, 15-102.

Bátora/Furmánek 2015 - J. Bátora/V. Furmánek: Spracovávanie neželezných kovov. In: V. Furmánek (zost.): Staré Slovensko 4. Doba bronzová. Nitra 2015, 277-279.

Budaváry 1930 - V. Budaváry: Hromadný medený nález z Handlovej (okr. Prievidza). Sborník Muzeálnej slovenskej spoločnosti 24, 1930, 95-98.

Jiráň a kol. 2008 - L. Jiráň (ed.) a kol.: Archeologie pravěkých Čech 5. Doba bronzová. Praha 2008.

Mádl 1936 - J. Mádl: Nález medených platní v Kočovciach (okr. Nové Mesto nad Váhom). Sborník Muzeálnej slovenskej spoločnosti 30, 1936, 110-111.

Rukopis prijatý 11. 5. 2020

Translated by Stephanie Staffen
Novosedlík 2002 - P. Novosedlík: Nález medeného koláča v Hlohovci. AVANS 2001, 2002, 143, 144.

Novotná 1955 - M. Novotná: Medené nástroje a problém najstaršej taažby medi na Slovensku. Slovenská archeológia 3, 1955, 70-100.

Sitár a i. 2012 - A. Sitár/V. Lapčík/M. Rusko/V. Dirner: Nálezy historických medených zliatkov z okolia Španej doliny. In: M. Rusko (ed.): Sustainability-Environment-Safety 2012. Zborník z konferencie s medzinárodnou účast’ou, 3. 12. 2012 Bratislava. Žilina 2012, 273-285.

\section{INTERNETOVÉ ZDROJE}

www.mapserver.geology.sk [16-04-2020].

www.podnemapy.sk [16-04-2020].

www.mapy.hiking.sk [16-04-2020].

PhDr. Zdeněk Farkaš, PhD.

Slovenské národné múzeum-Archeologické múzeum

Žižkova 12

SK - 81436 Bratislava

zdenek.farkas@snm.sk 


\title{
Copper Ingot from Chtelnica
}

\author{
Z deněk Farka š
}

SUMMARY

The conical-shaped copper ingot (Fig. 1; 2) comes from the Lesser Carpathians mountains, near the village of Chtelnica, Pieštany district (south-western Slovakia), from near a Late Stone Age and Later to Later Bronze Age settlement. The compact lump of casting with its porous structure has retained the inner shape of the thermic equipment with a flat bottom and walls which widen out conically to the top. Unlike the edges, the centre of the lump was porous, which allowed the casting to disintegrate into several separate parts. According to the monolithic patina, however, the disintegration took place a long time before the ingot was lifted from the ground (Fig. 2).

The item stands out particularly by its height in relation to the known forms of raw material from the Eneolithic to the early Modern Age (Sitár a i. 2012, 273, 274). The thickness of the ingot from Chtelnica $(11.9 \mathrm{~cm})$, the compactness of its material and weight $(4.654 \mathrm{~g})$ indicate mastery of the technological process of the essential alternation of oxidation and reduction (Jirán a kol. 2008, 12). The molten metal could have been taken from the oven by means of

Fig. 1. Map of Lesser Carpathian mountains near the village of Chtelnica. 1 - Pálenice, the place of find the conical-shaped copper ingot; 2 - Old Chtelnica and Pálenice, expected extend of the Late Stone Age settlement (source: https://mapy.hiking.sk/).

Fig. 2. Chtelnica, archaeological place Pálenice. Copper ingot. 1 - views of the ingot from different sides; $1 \mathrm{c}$-top side with traces of surface treatment in plastic a 'tap' and poured into the prepared ceramic mould or the mould dug into the earth. Subsequent treatments, primarily the marks left from removing the slag from the surface of the lump were carried out shortly after the melting, at a time when the mass was still in a partially plasmatic state.

The unusual shape of the lump of raw material and the unknown circumstances of its find do not enable a clear chronological classification of the item, although most of the clues point to a more recent, perhaps post-prehistoric origin. The chemical composition of the material was examined by ED-XRF analysis using a DELTA CLASSIC+ handheld X-ray fluorescence spectrometer by Olympus, USA (J. Tirpák) at the Faculty of Natural Sciences, University of Constantine the Philosopher in Nitra, and using the ED-XRF method and Inductively Coupled Plasma Optical Emission at the Institute of Geological Science of the Faculty of Natural Sciences of Masaryk University in Brno, showing a primary raw material probably matching chalcopyrite.

condition; 2, 3-details of the top side: A - traces after the 'slag' removal; B - secondary corrugated flipping of a thin layer of metal, $1 \mathrm{~d}$ - the bottom part of ingot: $\mathrm{C}$-traces of hammer with square head blows; 4,5 -detail of the surface (photo by Z. Farkaš).

Table 1. Chtelnica. Copper ingot from Chtelnica. Comparation table with the chemical composition of the ingot. 
